\title{
A NEW SPECIES OF PHYLLODISTOIMUM (TREMATODA: GORGODERIDAE, LOOSS, 1899) FROIM FRESHWATER FISH WALLAGO ATTU IN AKOLA DISTRICT (M.S.) INDIA
}

KEY WORDS: Akola, Gorgoderidae, Phyllodistomum Trematoda, Wallago attu.

\section{Ravi Khade*}

Amol Thosar

\section{Sachin Tayade}

Department of Zoology, Late Pushpadevi Patil Arts And Science College, Risod, Tq. Risod Dist.Washim. *Corresponding Author

Department of Zoology,Vivekanand College, Aurangabad.

Department of Zoology, Late Pundalikrao Gawali Arts and Science College Shirpur (Jain), Tq. Malegaon Dist.Washim

The present investigation deals with the systematic observation of a new species of Phyllodistomum khadensis Sp. Nov. from fresh water fish Wallago attu. The worm is close to all species of genus phyllodistomum in general the body is narrow while the posterior portion of the body is broad and triangular in shape. The oral sucker is terminal. The ventral sucker is rounded in structure and larger than oral sucker. The bladder is long and tubular.The anterior testis is smaller than posterior one. Vas deferans is long, tubular and forms vasa efferentia. Female reproductive organ includes single ovary having its duct. The vitelline glands are two in number compact lobes on either side of the ootype. The eggs are oval to round in shape.

\section{INTRODUCTION}

Braun (1899) erected the genus Phyllodistomum with Diplostomum folium v. as the type species. Yamaguti described two genera: Phyllodistomum, Braun, 1899 and Gorgotrema, Dayal, 1938 on the basis of number of testicular follicles. Dawes included the species from freshwater fishes under Phyllodistomum and those, from amphibian under Gorgoderidae, Looss, 1899. From India, it was first reported by Bhalerao from the intestine of Belonecancila and Ophiocephalus marulius and the stomach of Mastacembelus armatus. P. Vachius, Dayal J, 1949 from urinary bladder of E.vacha at Lucknow. Kaw, B. I. 1950 described Phyllodistomum loosi from Schizothorax socinus from Kashmir. P. singhiai, Gupta, S. P., 1951(b) from intestine of a freshwater fish Mastacembelus armatus (Lac.). Phyllodistomum lysteri, Phyllodistomum chauhani and Phyllodistomumt ripathi (Motwani, M. P. and H. F. Nagaty. 1980) from the urinary bladder of Mystus (Osteobagrus) aor (Ham), Mystus seenghala (Skyes), Bagarius bagarius from Allahabad (U.P.).

Phyllodistomum spatulaforme (Gupta, S. P. and S. L. Verma, 1977.) from the intestine of freshwater fish Ophiocephalus punctatus from River Gomti, Lucknow. P. funduli (Jaclyn Helt, John Janovy, Jr., and John Ubelaker, 2003) was recorded from Fundulusscia dicuscope from cedar creak in Western Nebraska. Phyllodistomum triangulate (Sarwat M.S., 2011) from Mastacembelus armatus at Paithan, Aurangabad, (M.S.), India. Naz, S. S. and Siddique S.F., 2012 proposed Phyllodistomum parichhaii and Phyllodistomum pahujii from intestine of Xenentodon cancila (Ham.) at Jhanshi India. Anu Prasanna Vankaraet al., 2014 reported Phyllodistomum batrachii from Clarias batrachus (Linn.) at Visakhapatnam (A.P.) India.

The present investigation deals with a new species of genus Phyllodistomum, Brawn i.e. Phyllodistomum khadensis, Sp.Nov. from fresh water fish Wallago attu in. Akola distrct (M.S.) India.

\section{MATERIAL AND METHODS}

Sixteen a like specimen of Phyllodistomum, Brawn were collected from Air bladder of fresh water fish, Wallago attu from Warkhed, Tehsil Telhara, Dist. Akola (M.S.) India, during the period of January 2013 to December 2014

These trematodes are preserved in hot $4 \%$ formalin and five specimens are stained with Harris haematoxylin and Borax carmine, dehydrated in ascending grades of alcohol, cleared in xylene, mounted in D.P.X. and drawings are made with the aid of Camera lucida attachments. Photomicrographs were taken by Trinocular computerized Research microscope. All measurements are recorded in millimeters.

www.worldwidejournals.com

\section{RESULT AND DISCUSSION}

\section{DESCRIPTION:}

The body of the fluke is dorso-ventrally flattened. The anterior portion of the body is narrow while the posterior portion of the body is broad and triangular in shape. The anterior end is rounded and is broad at the base. The trematode measures 20.25 (20.00-20.50) $\mathrm{mm}$ in length and 6.804 (6.654-6.954) $\mathrm{mm}$ in width. The oral sucker is terminal and oval in shape. It measures $0.483(0.425-0.541) \mathrm{mm}$ in length and $0.580(0.549$ $0.612) \mathrm{mm}$ in width. The ventral sucker is rounded in structure and larger than oral sucker and is situated in the anterior region of the body. It measures $0.552(0.510-0.595) \mathrm{mm}$ in length and $0.497(0.485-0.509) \mathrm{mm}$ in width and present at a distance of $3.845 \mathrm{~mm}$ from the anterior end of the body. The excretory pore present at the posterior end of the body and leads into an excretory bladder. The bladder is long and tubular. The genital pore is at a distance of 0.875 from the anterior end of the body. The testes are two in numbers. The anterior testis is smaller than posterior one.The anterior testis is $0.33(0.31-0.35) \mathrm{mm}$ broad and is present at a distance of $4.126 \mathrm{~mm}$ from the anterior end of body. The posterior testis is $0.41(0.39-0.43) \mathrm{mm}$ broad and is situated at a distance of $4.512 \mathrm{~mm}$ from anterior end of the body. The cirrus sac is oval measures 1.169 (1.023-1.315) $\mathrm{mm}$ in length and $0.929(0.782-$ $1.076) \mathrm{mm}$ in width and is situated $3.425 \mathrm{~mm}$ away from anterior extremity. Seminal vesicles tube like. Vas deferens is long, tubular and forms vasa differentia, measures 1.778 (1.691-1.865) $\mathrm{mm}$ length and $0.057(0.049-0.065) \mathrm{mm}$ in width. Vas differentia is long, runs posteriorly and measures 9.69 (09.12-10.26) in length.

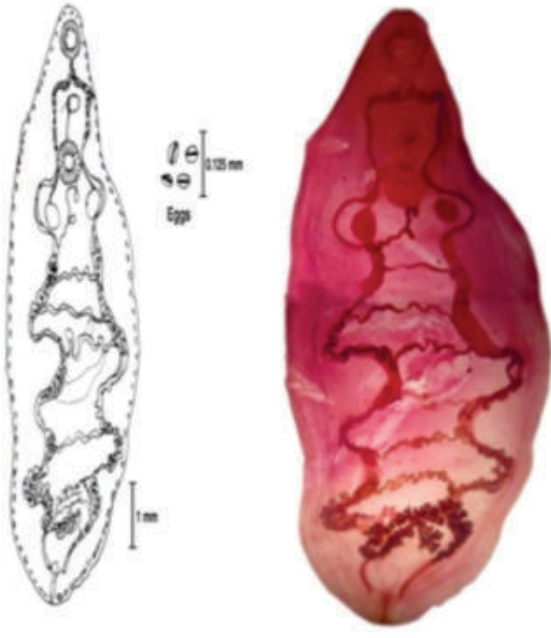

Fig. 1:- Phyllodistomum khadensis, Sp.Nov. 
Female reproductive organ includes single ovary having its duct and other of accessory organs accompanied with it. The ovary is oval. It is present before testis. The ovary measures $1.692 \mathrm{~mm}$ in diameter. From its anterior side arises the oviduct which opens at the ootype. The vitelline glands are two in number compact lobes on either side of the ootype. The right vitelline gland is $0.049(0.035-0.063) \mathrm{mm}$ in length and 0.027 (0.021-0.033) $\mathrm{mm}$ in width. Left vitelline gland measures 0.042 $(0.029-0.055)$ in length and $0.023(0.019-0.027)$ in width. The ducts arise from the two vitelline glands opens at the ootype. The eggs are oval to round in shape.

\section{DISCUSSION:-}

Phyllodistomum khadensis Sp.nov.is differs from Phyllodistomum folium has been reported in at least 10 different species of European Cyprinidae. A possible explanation for the wide range in host specificitycould be found in the life cycle of these species. The known life cycle of Phyllodistomum species can be found in 1 of 3 formats.

The described species differs from $P$. vachius, Dayal, J, 1949 in having anterior portion of body is long and curved while posterior portion of body broad; slightly curved, oval vitelline lobes, posterio-lateral to acaetabulum, eggs nonoperculated.

It differs from P.loosi, Kaw B.I., 1950 by shape of the body, structure of oral sucker as well as acetabulum. Size of vitelline lobes.

The recovered species is differs from $P$. singhiai Gupta, S. P., 1951 (b) in having inter caecal, lobed testes and below equilibrium. position of oval, ovary just behind right vitelline lobe, parallel to anterior testis, posterio-lateral to ventral sucker, eggs are oval, non-operculated.

The Phyllodistomum khadensis, Sp.nov.differ from P. lysteri, Fischthal, J.H, 1952, with post-equatorial, inter caecal, lobed testes. Position of oval, ovary behind right vitelline lobe, middle side genital pore just below the bifurcated intestine.

It differs from P.chauhani, Motwani M.P. and C. B. Srivastava, 1961 in having structure of acetabulum. Anterior testis is larger than posterior one, position of the ovary, size of vitelline lobes.

The present trematode parasite differs from $P$. tripathii, Motwani and Srivastava, 1961 in having body narrow at anterior side and broad softat posterior side, testes were oblique, ovary was only one, small, vitellaria having two lobes and reported from Mastacembelus armatus and $E$. vacha.

It differs from P.spatulaeforme, Gupta S.P. and Verma S. L., 1977 in having Ovary opposite and slightly opposite to vitelline gland and spatulated structure. Vitelline glands are distinct opposite to ovary.

The described specimen of trematode differs from P.funduli, Jaclyn Helt, John Janovy, Jr., and John Ubelaker,2003 in having Body slightly narrow at anteriorly end and broad and rounded at posterior side, Oral sucker large as compare to ventral sucker, oesophagus relatively straight, slender; muscular pharynx absent; vitelline glands posterior lateral to ventral sucker; oval, rarely lobed, present near the ventral sucker, Ovary amphitypic, sometimes slightly lobed; Uterus extensive, covering much of the hind end and with number of extracecal loops. Egg small, Testes present in broad part of the hind end, placed obliquely, and lobed, Seminal vesicle before ventral sucker, saclike in appearance reported from Fundulussciadicuscope from cedar creek in Western Nebraska.

It differs from $P$. triangulate, Sarwat M.S., 201 lin having the body is dorso-ventrally flattened. The anterior portion of the body is long and narrow while the posterior portion of the body is broad, expanded and nearly triangular in shape. The oral sucker is sub-terminal and oval in form. Ventral sucker is circular in form and larger than oral sucker and is situated in the equatorial region of the body. The bladder is long and tubular extending up to posterior testis. It gives out three lateral branches near testicular region. The genital pore is pre bifurcal. The testes are two in numbers, deeply lobed, inter caecal and lies obliquely one behind the other. Each testis possesses six or seven lobes. The anterior testis is bigger than posterior one. Single ovary with its duct and a number of accessory organs associated with it. The ovary is trilobed.

The vitelline glands are two compact lobes on either side of the ootype. The ducts from the two vitelline glands opens separately at the ootype. A Laurer's canal is present. The ootype is surrounded by a large number of shell gland cells. The uterus is not distinct. The eggs are absent.

The Phyllodistomum khadensis, Sp.nov. differ from $P$. parichhaii, Naz, S. S. and Siddique S.F., 2012 in having body spatulate, devided in to a narrow tubular fore body and expanded spatulate hind body, Oral sucker, at the terminal part of body, oval, sub-spherical, Pre-pharynx absent, Pharynx oval, Oesophagus short, tube like, oesophagus bifurcates into two unbranched intestinal caeca which Acaetabulum, spherical, large than oral sucker, Vitelline gland two, posterior lateral to acetabulum, Left vitelline gland nearby to ovary, Testes two, present in the broad part of the body, post-equatorial, tandem and deeply lobed and reported from intestine of a freshwater fish Xenentodoncancila (Ham.) caught in the different water bodies, district Jhansi Bundelkhand region.

The recovered specimen differs from Phyllodistomum pahujii, Naz, S. S. and S.F. Siddique, 2012 in having body spatulate, devided in to a narrow tube like fore body and expanded spatulate hind body, Oral sucker, present at terminal position, oval, sub-spherical, Pharynx and pre-pharynx were absent, Oesophagus curved tube like. Acetabulum, Sub-spherical, large as compared to oral sucker, Vitelline gland two, posterolateral to acetabulum. Right vitelline gland is nearby to ovary, Left vitelline gland saccular, near to anterior testis, Testes two, present in the broad part of the body, postequatorial, tandem, inter-caecal, deeply lobed, Ovary oval, after equatorial region, inter-caecal, just behind left vitelline gland, tandem to anterior testis, , Seminal vesicle, before acetabulum, saccular in structure. Genital pore middle just blow the intestinal bifurcation, Excretory bladder, tube like, excretory pore median, Eggs, oval and reported from intestine of Xenentodoncancila (Ham.) collected from various water bodies, district Jhansi Bundelkhand region.

Phyllodistomum khadensis, Sp. nov. differs from Phyllodistomum batrachii, Anu Prasanna Vankara, Mannela Hemalatha, C. Srinivasa Kalyan, C.Vijayalakshmi, 2014 in having Body small, creamy white in colour with slightly narrow anteriorly and broad posteriorly. Oral sucker sub- terminal in position, small than ventral sucker. Pharynx absent. Oesophagus short, Intestinal bifurcation before ventral sucker, intestinal caeca sinous, end near the posterior side and not extend upto past uterus, ventral sucker large, round. Testes two, inter caecal, after ovary, after acetabulum, slightly lobed, Seminal vesicle bipartite, before ventral sucker, globular. Cirrus sac absent, Ovary oval, large, after ventral sucker.Vitelline glands paired, after ventral sucker and oval. Uterus extensive, occupying much of the hind part body and extends forward to form metraterm which lastly opens into genital atrium. Genital atrium median, opens lateral side to oesophagus. Eggs small, round, faint brown in color and collected from Clarias batrachus (Linn.) from the river Godavari, Rajahmundry.

From the aforesaid discussion it is prove that the species under discussion is new to science and differs from known 
valid species of genus. According to all significant differentiating characters of new trematode, author described as a new species Phyllodistomum khadensis, sp.nov. The described species is named after a surname of main author because of contribution of author in this work.

\section{REFERENCES}

1. Amato S.B and J.F.R. Amato (1993). A new species of Phyllodistomum, Braun, 1899 (Digenea: Gorgoderidae) from Rhamdia quelen (Quoy \& Gaimard, 1824) (Siluriformes: Pimelodidae). Mem. Inst. Oswaldo Cruz, Rio de Janeiro, vol.88 (4):557-559.

2. Berenice M.M. Fernandes (1984). New host, Geographical Record and A Synonym for Phyllodistomum Spatula Odhner, 1902 (Trematoda, Gorgoderidae).Mem.Inst.Oswaldo Cruz, Rio de Janeiro, vol. 79 (2):263-265.

3. Braun, M (1899). Trematode der dhal'schen sammlung aus nev Guinea. Centr.Bakt.Parasit, abt. 25-29.

4. Dawes, B (1947). The Trematoda of British Fishes. The Ray Society, London. 344.

5. Dayal, J (1938). Trematode parasites of Indian fishes, part II. Ind. Jour. Helm, I (2):93-116.

6. Gupta, S. P (1951). On a new trematode Phyllodistomum singhiai, n.sp. of the family Gorgoderidae Looss, 1899 from the intestine of a freshwater fish Mastacembelus armatus (Lacep).Ind Jour.Helm.3 (1):21-28.

7. Gupta, S. P (1951): On a new trematode Phyllodistomum singhiai, n.sp. of the family Gorgoderidae Looss, 1899 from the intestine of a freshwater fish Mastacembelus armatus (Lacep). Ind.Jour. Helm.3 (1):21-28.

8. Gupta, S. P and S. L. Verma (1977). On some trematode parasites of freshwater fishes. Riv.Parasit.37 (2/3): 171-182.

9. Helt, J., J. Janovy, Jr., and J.Ubelaker (2003). Phyllodistomum funduli, n. sp. (Trematoda: Gorgoderidae) from Fundulussciadicus Cope from Cedar Creek inWestern Nebraska.J. Parasitol., 89(2):346-350.

10. Ho et.al. (2014). Two new species of Phyllodistomum ,Braun, (Trematoda: Gorgoderidae, Looss, 1899) from Great Barrier Reef fishes.Zootaxa 3779(5):551-562.

11. Jacob H. Fischthal (1952). A Redescription of Phyllodistomum lysteri Miller, 1940 (Trematoda: Gorgoderidae) from the Common White Sucker. The Journal of Parasitology, pp. 242-244.

12. Jag Mohan Sen, (2014). On a New Species of Phyllodistomum Braun, 1899 (Digenea: Gorgoderidae), a Parasite of Fresh Water Fish, Channa punctatus (Bl.) from Betwa River, Bundelkhand Region Jhansi, U.P, India. Current World Environment.Vol.9(1), 207-209.

13. Kaw, B.I (1950). Trematodes from Kashmir.Ind.Jour.Helm.2:107-110.

14. Motwani, M. P. \& C. B. Srivastava. (1961). On two phyllodistomes from the urinary bladder of siluroid fishes (Trematoda: Gorgoderidae). Indian Journal of Helminthology 13:93-99.

15. Naz, S. S and S. F. Siddique (2012). Two new digenetic trematodes Phyllodistomum parichhaii and Phyllodistomum pahujii (family: Gorgoderidae, Looss, 1901) from fresh water fish Xenentodoncancila (Ham.) of different water bodies, District Jhansi Bundelkhand Region. International Journal of Innovations in Bio-Sciences.2 (4):229-231.

16. Sarwat M. S (2011). A New Species of the Genus Phyllodistomum (Braun, 1899) (Digenea: Gorgoderidae, Looss, 1901) from Freshwater Fish Mastacembelus armatus, Aurangabad (M.S.) India. Recent Research in Science and Technology, 3(8): 11-13.

17. Sen. J .M (2014). On a New Species of Phyllodistomum Braun, 1899 (Digenea: Gorgoderidae), A Parasite of Fresh Water Fish, Channa Punctatus (BL.) From Betwa River, Bundelkhand Region Jhansi, U.P, India. Current World EnvironmentVol.9(1),207-209.

18. Takeshi Shimazu (2014). Digeneans Parasitic in Freshwater Fishes (Osteichthyes) of Japan. II. Gorgoderidae and Orientocreadiidae. Bull. Natl. Mus.Nat.Sci., Ser.A, 40(2), pp.53-78.

19. Yamaguti, S. (1958). Systema Helminthum Vol. I. The digenic Trematodes of vertebrates.Int. Sci.Pub.NewYork. 1575.

20. Yamaguti, S(1971). Synopsis of digenetic trematodes of Vertebrates, Keigaku Publishing Co.Tokyo Japan. 1-1074.

21. Yamaguti, S(1975). A synoptical review of life histories of digenetic trematodes of vertebrates. Keigaku Publishing Co.Tokyo, Japan, 1-590. 